\title{
Jawność wynagrodzeń w kontekście budowania wizerunku pracodawcy
}

\author{
Urszula Zając-Pałdyna \\ Instytut Kapitału Ludzkiego, Kolegium Nauk o Przedsiębiorstwie, \\ Szkoła Główna Handlowa w Warszawie
}

\begin{abstract}
Celem artykułu jest analiza jawności wynagrodzeń w kontekście budowania marki/wizerunku pracodawcy. W artykule dokonano przeglądu definicji pojęcia wizerunku przedsiębiorstwa jako pracodawcy, przeanalizowano koncepcję budowania marki pracodawcy oraz pojęcia employee value proposition (EVP). Dokonano analizy obszaru jawności wynagrodzeń w kontekście uregulowań prawodawstwa oraz z punktu widzenia dotychczasowego dorobku badawczego. Wyniki badań empirycznych dostarczyły oceny wizerunku pracodawców oraz obszaru jawności wynagrodzeń wśród polskich pracodawców. Wnioski posłużą do dalszych badań na temat jawności wynagrodzeń w kontekście budowania marki pracodawcy.
\end{abstract}

Słowa kluczowe: jawność wynagrodzeń, wizerunek pracodawcy, marka pracodawcy

\section{Wprowadzenie}

Rynek pracy, na którym pracownicy starają się o miejsca pracy, a pracodawcy rywalizują o pracowników, podlega wielu wpływom. Sytuację na rynku pracy determinują zarówno czynniki ekonomiczne, społeczne, technologiczne, jak i naciski polityczne. Warto także sytuację na rynku pracy rozpatrywać z perspektywy organizacyjnej oraz elementów wpływających na poziom zatrudnienia czy też wynagrodzeń (Szaban, 2013, s. 15). Wśród wielu czynników kształtujących rynek pracy uwagę przykuwa obecna stopa bezrobocia rejestrowanego w Polsce. Kiedy przeanalizuje się poziom bezrobocia na przestrzeni kilku ostatnich lat, można zauważyć, że stopa ta stale spada i, przykładowo, w kwietniu 2018 r. osiągnęła poziom 6,3\%, kiedy jeszcze pięć lat wcześniej, w tym samym miesiącu, w 2013 r., była ponad dwa razy wyższa - na poziomie 14\% (GUS, 2018). Niska stopa bezrobocia, starzenie się 
społeczeństwa, kurczenie się rynku pracy, a także niedobór talentów spowodowały problemy pracodawców z pozyskaniem odpowiedniej kadry. Dodatkowym czynnikiem powodującym problemy z pozyskiwaniem pracowników, na który warto zwrócić uwagę, jest odmienne postrzeganie pracy przez młode pokolenia obecne na rynku pracy. Przedstawiciele pokolenia Y czy Z cenią sobie różnorodność, zdobywanie kolejnych doświadczeń i nie są tak samo lojalni wobec pracodawców, jak przedstawiciele starszych pokoleń - X czy Baby Boomers. Osoby ubiegające się o pracę, zwłaszcza młode, cenią w pracodawcach transparentność, także w kwestii wynagrodzeń. To właśnie kłopoty pracodawców z pozyskiwaniem pracowników, przekładające się pośrednio na realizację celów strategicznych firm, skłoniły przedsiębiorstwa do szukania wyróżników, których celem byłoby przyciągnięcie pożądanej kadry. Efektem sytuacji na rynku pracy oraz wyzwań, z jakimi mierzą się pracodawcy, jest wzrost zainteresowania przedsiębiorstw budowaniem marki/ /wizerunku pracodawcy (employer branding). Jednym z elementów budowy marki pracodawcy jest obszar wynagrodzeń, a ściślej - jawności wynagrodzeń.

Celem artykułu jest analiza jawności wynagrodzeń w kontekście budowy marki pracodawcy. Analiza literatury pozwoliła na zdefiniowanie pojęcia wizerunku pracodawcy oraz pokazanie istoty koncepcji marki pracodawcy. Przeanalizowano polskie ustawodawstwo, które odnosi się, w głównej mierze, do kwestii jawności zarobków konkretnych pracowników i rozpatruje je jako dobra osobiste. Badania opinii pracowników, które zostały przeprowadzone w ramach grantu pt. Sprawiedliwość wynagradzania, finansowanego przez Narodowe Centrum Nauki, dostarczyły wyników, na których podstawie można wysnuć wnioski, że działania pracodawców w obszarze wizerunku pracodawcy są zauważalne przez pracowników, jednak wciąż spora grupa pracujących Polaków nie ma wiedzy na temat tego, jak są ustalane zasady ich wynagrodzeń. Temat artykułu i badania należy poszerzyć o bardziej szczegółowe analizy w kontekście jawności wysokości wynagrodzenia oraz sposobów komunikacji zasad wynagradzania w przedsiębiorstwach.

\section{Wizerunek pracodawcy}

Zarządzanie marką pracodawcy zalicza się do grupy najnowszych koncepcji zarządzania organizacją, a czerpie ono $z$ marketingu oraz nauki o organizacji i zarządzaniu. W literaturze nie ma zgodności co do daty powstania samej koncepcji wizerunku pracodawcy, brakuje też badań empirycznych, które przedstawiłyby kompleksowo istotę zjawiska. Pokłosiem tego, że obszar budowania wizerunku pracodawcy jest niezbadany i stosunkowo nowy, są problemy definicyjne oraz wielość ujęć employer branding. 
W literaturze przyjmuje się, że pierwszy raz posłużono się terminem employer branding w $1990 \mathrm{r}$. podczas konferencji organizowanej przez Chartered Institute of Personnel and Development, natomiast sama definicja employer branding została sformułowana w 1996 r. przez S. Barrowa oraz R. Mosleya (Ambler, Barrow, 1996, s. 187). Według tych autorów definicji, employer branding to suma funkcjonalnych, ekonomicznych oraz psychologicznych korzyści z bycia zatrudnionym i identyfikowania się z organizacją. Twórcy definicji kładą więc nacisk na wartości, jakie przynosi interesariuszom zatrudnienie i praca w danej firmie. Przez interesariuszy należy rozumieć osoby, które pracują w danym przedsiębiorstwie oraz osoby ubiegające się o pracę, bowiem to głównie one są odbiorcami działań z zakresu kreowania marki pracodawcy. Mówi się zatem o interesariuszach obecnych i potencjalnych. W ocenie autorki, takie rozumienie interesariuszy może budzić wątpliwości, gdyż pomija istotną grupę interesariuszy, jakimi są byli pracownicy. Zdaniem autorki, byli pracownicy poprzez swoje działania mają wpływ na odbiór wizerunku firmy jako pracodawcy. To oni bowiem dziś przekazują komunikaty na temat pracodawców, które są odczytywane przez osoby ubiegające się o pracę, a tym samym tworzą $w$ ich oczach obraz danej organizacji. Istotne wydają się więc także działania z zakresu budowania marki pracodawcy, skierowane do osób odchodzących z organizacji lub już będących poza nią.

Ujęć wizerunku przedsiębiorstwa jako pracodawcy jest wiele, jednak istota koncepcji employer branding trafnie została ujęta w definicji K. Wojtaszczyk (2012, s. 86), a brzmi ona następująco: employer branding to proces kreowania wartości dla interesariuszy, które powstają na skutek legitymowania się przez organizację silną marką pracodawcy, a marka pracodawcy to suma korzyści, jakie przynosi wszystkim podmiotom zaangażowanym jako nadawcy lub odbiorcy w proces jej budowania. W istocie każde przedsiębiorstwo ma jakąś markę pracodawcy, dopiero praca nad marką, jej umacnianie i wysiłki z tym związane można nazwać zarządzaniem marką pracodawcy.

Budowa marki pracodawcy opiera się na tzw. EVP (employee/employer value proposition), czyli propozycji wartości/oferty, która odróżnia pracodawcę od innych podmiotów oferujących zatrudnienie i która stanowi podstawę działań z zakresu employer branding danej organizacji (Browne, 2012, s. 30). EVP dla pracownika jest zbiorem korzyści, które organizacja dostarcza w zamian za umiejętności, zdolności, kompetencje i doświadczenie, które wnosi on do firmy. Korzyści, nazywane również składowymi EVP, można pogrupować w zbiory przedstawione przykładowo w tabeli 1.

Propozycja wartości stworzona dla pracowników powinna obejmować wszystkie rodzaje korzyści, a jednocześnie zapewniać równowagę między efektywnością organizacji a oczekiwaniami pracowników. 
Tabela 1. Przykładowe składniki EVP

\begin{tabular}{|c|c|c|}
\hline Korzyści racjonalne & $\begin{array}{l}\text { Korzyści emocjonalne } \\
\text { i autoekspresywne }\end{array}$ & $\begin{array}{c}\text { Korzyści wynikające } \\
\text { z obecnego wizerunku marki }\end{array}$ \\
\hline $\begin{array}{l}\text { - } \text { Poziom wynagrodzenia } \\
\text { - Świadczenia pozapłacowe } \\
\text { - Bezpieczeństwo i pewność } \\
\text { zatrudnienia } \\
\text { - Możliwości rozwoju } \\
\text { zawodowego i awansu } \\
\text { - Możliwość pogodzenia } \\
\text { życia prywatnego } \\
\text { z zawodowym }\end{array}$ & $\begin{array}{l}\text { - Środowisko pracy } \\
\text { - Atmosfera w zespole } \\
\text { - Styl kierowania } \\
\text { - Satysfakcja płynąca } \\
\text { z wykonywania } \\
\text { konkretnych obowiązków } \\
\text { i ich zróżnicowanie } \\
\text { - Poziom odpowiedzialności } \\
\text { i autonomii pracownika } \\
\text { - Prestiż stanowiska } \\
\text { - Zgodność wartości } \\
\text { wyznaczanych przez firmę } \\
\text { z wartościami osobistymi }\end{array}$ & $\begin{array}{l}\text { - Przynależność do } \\
\text { międzynarodowej grupy } \\
\text { firm } \\
\text { - Kraj pochodzenia } \\
\text { organizacji i związane } \\
\text { z nim dobre skojarzenia } \\
\text { - Znana marka firmy } \\
\text { - Znana marka produktów } \\
\text { - Znane osoby/autorytety } \\
\text { - } \text { - Prirmie } \\
\text { przyszłe sukcesy } \\
\text { organizacji }\end{array}$ \\
\hline
\end{tabular}

Źródło: Wojtaszczyk (2012, s. 107).

Jednym z elementów i filarów EVP jest obszar wynagrodzeń pracowniczych. Same wynagrodzenia jednak, nawet jeśli są na wysokim poziomie względem rynku, nie mogą stanowić jedynego filaru propozycji wartości, powinny być bowiem uzupełnione o pozostałe korzyści, które wspólnie z wynagrodzeniem pozwolą przyciągnąć, zatrzymać i motywować kadrę (Hill, Tande, 2006, s. 20). Praktyka gospodarcza dostarcza przykładów, które pokazują, że coraz więcej przedsiębiorstw decyduje się na jawność w obszarze płac już na etapie pozyskiwania pracowników. Takie działania pracodawców należy zaliczyć do działań z zakresu budowy marki pracodawcy i mogą one stanowić wyróżnik firmy na rynku pracy. Na uwagę zasługuje instytucja jawności wynagrodzeń, zwłaszcza w kontekście obowiązujących w Polsce uregulowań prawnych.

\section{Jawność wynagrodzeń}

Obszar wynagrodzeń od wielu lat budzi zainteresowanie teoretyków i praktyków. Na uwagę zasługuje kwestia sprawiedliwości wynagrodzeń, która może być oparta na dwóch rodzajach komponentów: obiektywnych oraz subiektywnych. Obiektywna percepcja polega na logicznym powiązaniu wysokości wynagrodzenia z rynkiem zewnętrznym, natomiast subiektywna odnosi się do emocjonalnej reakcji pracownika na wartość, jaka została wygenerowana poprzez wynagrodzenie. Poczucie sprawiedliwości wynagradzania przez pracowników może wynikać z trzech czynników: 
1) rozumienia sposobu ustalania wysokości wynagrodzenia,

2) wiedzy, w jaki sposób można zmaksymalizować wysokość wynagrodzenia,

3) powiązania wysokości wynagrodzenia $z$ wydajnością.

Postrzeganie sprawiedliwości wynagradzania przez pracowników jest, w dużej mierze, determinowane przejrzystością systemu wynagrodzeń. Pracownicy, którzy mają wgląd do systemu płac i świadczeń pozapłacowych, rozumieją system płac oraz wiedzą, jak na niego wpływać, również uznają, że system jest bardziej sprawiedliwy. Kluczowym elementem poczucia sprawiedliwości wynagrodzeń jest nie poziom wynagrodzeń, ale jawność systemu oraz filozofii płac. Istotną rolę odgrywa także komunikacja oraz rola specjalistów ds. wynagrodzeń oraz świadczeń pozapłacowych (Rasch, Szypko, 2013, s. 65-67).

Kwestię jawności wynagrodzeń w Polsce należy rozpatrywać w pierwszej kolejności z perspektywy obowiązującego ustawodawstwa. Może się bowiem okazać, że ujawnienie wynagrodzeń na etapie pozyskiwania osób do pracy, np. w ogłoszeniu o pracę, będzie niosło za sobą konsekwencje w postaci ujawnienia wynagrodzenia konkretnego pracownika. Sytuacja taka może mieć miejsce w przedsiębiorstwach, w których pracuje tylko jedna lub kilka osób na tym samym lub podobnym stanowisku.

W orzecznictwie przyjmuje się, że informacja o wynagrodzeniu pracownika może stanowić jego dobra osobiste, a co za tym idzie - powinna być chroniona. Już Konstytucja RP (1997) w art. 47 stanowi, że każdy ma prawo do ochrony prawnej życia prywatnego, a więc można domniemywać, że wynagrodzenie pracownika również powinno być chronione. Ujawnienie wynagrodzeń należy także rozpatrywać na tle uregulowań Kodeksu cywilnego (Ustawa..., 1964), a konkretnie art. 23 i 24 . W art. 23 k.c. ustawodawca wymienia dobra osobiste człowieka, które pozostają pod ochroną prawa cywilnego. Katalog dóbr osobistych podlegających ochronie jest katalogiem otwartym, a więc można domniemywać, że ujawnienie wysokości wynagrodzenia konkretnej osoby może stanowić naruszenie dóbr osobistych w rozumieniu art. 23 i 24 Kodeksu cywilnego. Także art. 11 ust. 1 Kodeksu pracy (Ustawa..., 1974) odnosi się do dóbr osobistych i nakazuje pracodawcy je szanować. Orzecznictwo Sądu Najwyższego, m.in. Uchwała Składu Siedmiu Sędziów z dnia 16 lipca 1993 r. (Sąd Najwyższy-Izba Pracy, 1993), nie jest jednak tak jednoznaczne w ocenie, czy ujawnianie wynagrodzeń należy rozpatrywać w kontekście naruszenia dóbr osobistych pracownika. Sąd Najwyższy uznał bowiem, że pojęcie naruszenia określonego dobra osobistego jest pojęciem dynamicznym w czasie i dotyczącym konkretnych zakładów pracy (Sąd Najwyższy-Izba Pracy, 1993). Inaczej bowiem należy ocenić sytuację, w której w danym przedsiębiorstwie praktyka jawności płac jest ukształtowana od lat, a dodatkowo jest aprobowana przez pracowników, a inaczej w firmie, w której od początku ukształtowano zasadę 
nieujawniania wysokości wynagrodzeń poszczególnych pracowników i wyrażono to w regulacjach zakładowych lub umowach o pracę (Sąd Najwyższy-Izba Pracy, 1993). Do niedawna ujawnianie płac można było także rozpatrywać w kategoriach naruszenia danych osobowych na podstawie ustawy o ochronie danych osobowych (Ustawa..., 1997). W dniu 10 maja 2018 r. weszła w życie nowa ustawa o ochronie danych osobowych, która jednak nie zawiera poprzednich uregulowań (Ustawa..., 2018).

Polskie ustawodawstwo ujmuje kwestię jawności płac jedynie w kontekście ujawnienia wysokości wynagrodzenia konkretnego pracownika. W literaturze przyjmuje się jednak więcej aspektów jawności płac. Jawność może bowiem dotyczyć: sposobu ustalania systemu wynagrodzenia, kwestii komunikacji, a więc odnosić się do zakresu, w jakim pracownicy mają swobodę w zakresie rozmawiania na temat wynagrodzeń, a także jawności wysokości zarobków (Arnold i in., 2018, s. 3-4). Z badań przeprowadzonych w Szwajcarii wynika, że organizacje są bardziej skłonne do przekazywania pracownikom informacji na temat sposobu ustalania wynagrodzenia aniżeli rzeczywistego poziomu indywidualnego wynagrodzenia (Arnold i in., 2018, s. 3-4). Analiza rodzimych ogłoszeń o pracę także dostarcza wniosków, że pracodawcy w Polsce nie są chętni do ujawniania wysokości płac.

\section{Badanie wizerunku przedsiębiorstwa oraz jawności wynagrodzeń - wyniki}

Celem badania, które zostało zrealizowane w ramach grantu pt. Sprawiedliwość wynagradzania, finansowanego przez Narodowe Centrum Nauki, było poznanie opinii osób aktywnych zawodowo na temat postrzegania przez nich wynagrodzeń, a także obszaru jawności płac. Zespół badawczy, złożony z przedstawicieli Szkoły Głównej Handlowej w Warszawie oraz Uniwersytetu Warszawskiego, skonstruował ankietę, która została wykorzystana do przeprowadzenia w listopadzie 2017 r. badania przy użyciu techniki CATI (Computer Assisted Telephone Interviewing). Badaniem objęto reprezentatywną grupę dorosłych mieszkańców Polski ( $N$ = 1003). Na potrzeby niniejszego artykułu dokonano analizy odpowiedzi na pytania dotyczące wizerunku przedsiębiorstwa oraz jawności wynagrodzeń, a także dokonano charakterystyki respondentów.

Dobór próby był losowy, charakterystyka została przedstawiona w tabeli 2.

Jak wynika z tabeli 2, w badaniu nieznacznie przeważali mężczyźni (56\%), najliczniejszą grupę respondentów stanowiły osoby w wieku 45-59 lat (32\%) oraz w wieku 25-34 lata (31\%). Osoby w wieku 35-44 lata to 1/4 respondentów. Jeśli 
chodzi o zarobki, dochód respondentów podczas badania w większości oscylował w granicach 1401-2500 PLN (uzyskiwało go 30\% badanych) oraz 2501-3500 PLN (26\%). Najmniej liczna grupa badanych (3\%) zarabiała w trakcie badania między 7501 PLN a 10000 PLN oraz powyżej 10000 PLN (4\%).

Tabela 2. Charakterystyka respondentów

\begin{tabular}{|l|c|}
\hline \multicolumn{1}{|c|}{ Wyszczególnienie } & Udział w \% \\
\hline \multicolumn{2}{|c|}{ Płeć } \\
\hline Mężczyzna & 56 \\
\hline Kobieta & 44 \\
\hline \multicolumn{2}{|c|}{ Wiek } \\
\hline 18-24 lata & 6 \\
\hline 25-34 lata & 31 \\
\hline 35-44 lata & 25 \\
\hline 45-59 lat & 32 \\
\hline Powyżej 60 lat & 6 \\
\hline \multicolumn{1}{|c|}{ Dochód netto (w PLN) } \\
\hline Poniżej 1400 & 30 \\
\hline 1401-2500 & 26 \\
\hline 2501-3500 & 16 \\
\hline 3501-5500 & 6 \\
\hline 5501-7500 & 3 \\
\hline 7501-10 000 & \\
\hline Powyżej 10 000 & \\
\hline
\end{tabular}

Źródło: opracowanie własne.

Jak wynika z przeprowadzonych wywiadów, prawie połowa respondentów uznała, że przedsiębiorstwa, w których badani pracują, dbają o swój wizerunek jako pracodawcy także poprzez ustalanie wynagrodzeń - 30\% badanych zdecydowanie zgodziło się ze stwierdzeniem „Firma, w której pracuję, dba o swój wizerunek jako pracodawcy także poprzez ustalanie wynagrodzeń", a $26 \%$ respondentów zaznaczyło odpowiedź „Raczej się zgadzam” (rysunek 1). Prawie 1/4 ankietowanych (22\%) uznała, że firmy, w których badani pracują, nie dbają o employer branding (13\% wskazań dla odpowiedzi „Raczej się nie zgadzam” i 9\% dla „Zdecydowanie się nie zgadzam). Aż $21 \%$ badanych nie potrafiło udzielić odpowiedzi na zadane pytanie i zaznaczyło odpowiedź „Nie wiem/trudno powiedzieć” oraz „Ani się zgadzam, ani się nie zgadzam”. 
Rysunek 1. Firma, w której pracuję, dba o swój wizerunek jako pracodawcy także poprzez ustalanie wynagrodzeń

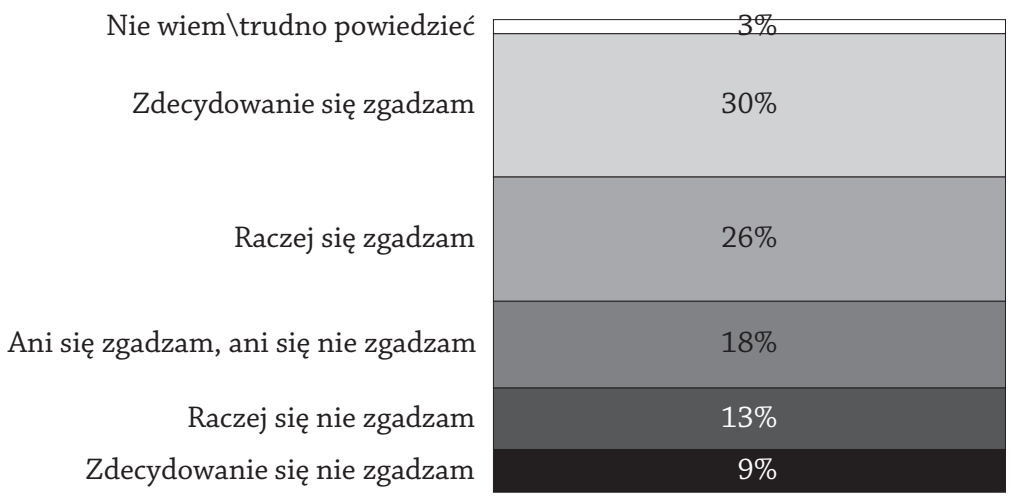

Źródło: opracowanie własne.

Podsumowując, należy wyrazić zadowolenie, że pracujący Polacy widzą wysiłki firm w obszarze budowania marki pracodawcy, zwłaszcza w kontekście wynagrodzeń. Niestety, prawie połowa z nich nie ma zdania lub nie widzi wysiłków pracodawców. Spora liczba negatywnych odpowiedzi oraz tych z obszaru „Nie wiem, trudno powiedzieć" może wynikać z połączenia w jednym pytaniu dwóch kategorii - wizerunku oraz kwestii wynagradzania. Taki rozkład odpowiedzi oznacza jednak, że przedsiębiorstwa mają przed sobą sporo wyzwań związanych z budowaniem i wzmacnianiem swojej marki jako pracodawcy i że ten obszar jest istotny.

Zna zasady ustalania wynagrodzeń w firmie, w której pracuje, 69\% badanych, a prawie połowa respondentów (48\%) zdecydowanie zgodziła się z tym stwierdzeniem (rysunek 2). Wskazało, że nie ma wiedzy na temat zasad ustalania swojego wynagrodzenia, $18 \%$ badanych, zaś aż $12 \%$ respondentów nie potrafiło ustosunkować się do tej kwestii.

Jak wynika z odpowiedzi, wciąż spora grupa osób nie ma informacji o tym, w jaki sposób jest ustalane wynagrodzenie w firmie, zatem może to wpływać na ich poczucie sprawiedliwości, nawet jeśli organizacje sprawiedliwie dzielą wynagrodzenia. Funkcjonuje nadal spora grupa pracujących Polaków, która nie zna zasad ustalania wynagrodzeń bądź nie potrafi się ustosunkować do tej kwestii. Wydaje się więc, że należy zadać bardziej szczegółowe pytania i sprawdzić, na ile pracodawcy dbają o aspekt komunikacji zasad wynagradzania w przedsiębiorstwach.

Respondenci w większości uważają, że zasady wynagradzania w firmach, w których pracują, są jawne (43\% wskazań dla odpowiedzi „Zdecydowanie się zgadzam” i 16\% dla „Raczej się zgadzam”) - rysunek 3. Nie potrafiło udzielić 


\section{Rysunek 2. Znajomość zasad ustalania wynagrodzeń w firmie}

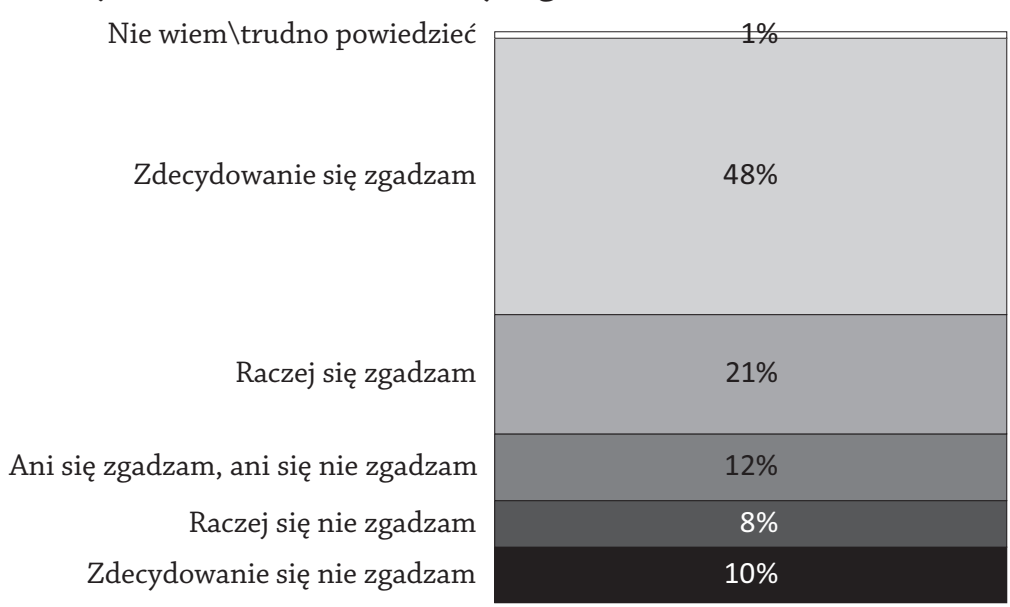

Źródło: opracowanie własne.

odpowiedzi 11\% ankietowanych, a ponad 1/4 (28\%) nie zgodziła się ze tym stwierdzeniem. Taki rozkład odpowiedzi pokazuje, że pracodawcy w Polsce mają trudność w ujawnianiu samych zasad wynagradzania, a jak wynika $\mathrm{z}$ analizy literatury oraz ogłoszeń o pracę w Polsce, ujawnianie kwoty wynagrodzenia jest rzadkością i dotyczy głównie zawodów deficytowych, zwłaszcza w obszarze IT.

\section{Rysunek 3. Jawność zasad wynagradzania w firmie}

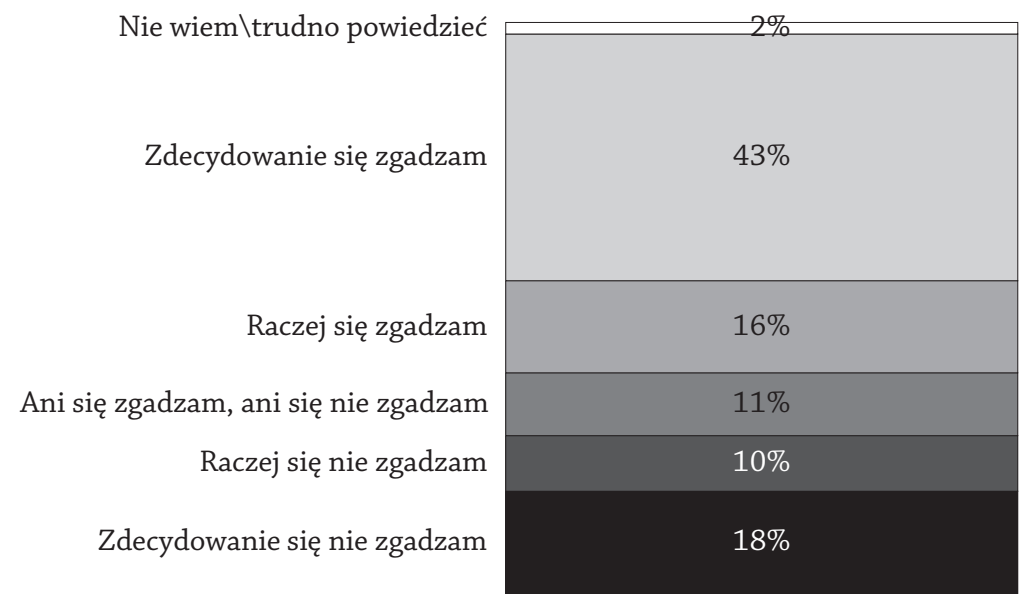

Źródło: opracowanie własne. 


\section{Podsumowanie}

Zarówno koncepcja wizerunku przedsiębiorstwa jako pracodawcy, jak i jawności wynagrodzeń są obszarami ważnymi nie tylko w kontekście zarządzania czy sprawiedliwości, lecz także z uwagi na wykorzystywanie tych obszarów w praktyce gospodarczej, zwłaszcza w kontekście wymagającego obecnie rynku pracy. Jawność zasad oraz odpowiednia ich komunikacja, a w najlepszej sytuacji jawność kwoty wynagrodzenia mogą stanowić istotny wyróżnik przedsiębiorstwa wśród konkurentów, co może stanowić o przewadze przedsiębiorstwa jako pracodawcy. Badania przeprowadzone na reprezentatywnej grupie Polaków jasno pokazały, że wspomniane obszary są ważne, zatem warto pogłębić badania i zapytać respondentów o kwestię komunikacji zasad wynagradzania oraz jawność kwoty wynagrodzeń. Analiza polskiego prawodawstwa wskazuje bowiem, że przepisy prawne nie muszą być barierą w jawności wynagrodzeń w Polsce.

\section{Bibliografia}

Ambler, T., Barrow, S. (1996). The employer brand. The Journal of Brand Management, 4(3), 185-206.

Arnold, A., Fulmer, I.S., Sender, A., Staffelbach, B. (2018). Compensation and pay transparency practices in Switzerland: Survey report (2018). https://www.researchgate. net/publication/322600300_Compensation_and_pay_transparency_practices_ in_Switzerland_Survey_report_2018 (3.08.2018).

Berthon, P., Ewing, M., Hah, L.L. (2005). Captivating company: Dimensions of attractiveness in employer branding. International Journal of Advertising, 24(2), 151-172.

Browne, R. (2012). Employee Value Proposition. Beacon Management Review, 29-36.

GUS (2018). Stopa bezrobocia rejestrowanego w latach 1990-2018. Warszawa.

Hill, B., Tande, Ch. (2006). Total rewards the employment value proposition. Tandehill Human Capital Consulting. www.tandehill.com/pdfs/total-rewards.pdf (3.08.2018).

Konstytucja Rzeczpospolitej Polskiej z dnia 2 kwietnia 1997 r. Dz.U. Nr 78, poz. 483.

Rasch, R., Szypko, M. (2013). Perception is Reality: The Importance of Pay Fairness to Employees and Organizations. WorldatWork Journal, Third Quarter, 65-74.

Sąd Najwyższy-Izba Pracy (1993). Uchwała Składu Siedmiu Sędziów Sądu Najwyższego z dnia 16 lipca 1993 r. Sygn. akt I PZP 28/93, nr 28174.

Szaban, J.M. (2013). Rynek pracy w Polsce i w Unii Europejskiej. Warszawa: Difin.

Taylor, S. (2005). People Resourcing. London: Chartered Institute of Personnel and Development. 
Ustawa z dnia 29 sierpnia 1997 r. o ochronie danych osobowych. Dz.U. z 2002 r. Nr 101.

Ustawa z dnia 26 czerwca 1974 r. - Kodeks pracy. Dz.U. 1974 Nr 24 poz. 141.

Ustawa z dnia 23 kwietnia 1964 r. - Kodeks cywilny. Dz.U. Nr 16, poz.93 z późn. zm. Ustawa z dnia 10 maja 2018 r. o ochronie danych osobowych. Dz.U. Nr 1000.

Wojtaszczyk, K. (2012). Employer branding, czyli zarzq̨dzanie markq pracodawcy. Uwarunkowania, procesy, pomiar. Łódź: Wydawnictwo Uniwersytetu Łódzkiego.

\section{Summary}

\section{Transparency of Remuneration in the Context of Building the Employer Branding}

The purpose of the article is to analyze the openness around remuneration in the context of building an employer's brand/image. The article reviews the definition of the employer branding concept. It analyzes as well the concept of building an employer's brand and employee value proposition (EVP). The Author attempted to the area of transparency remuneration idea in the legislation context as well as from the current research achievements point of view. The results of empirical research provided an assessment of the image of employers and the area of wages openness among Polish employers. The applications will be used for further research on the transparency of remuneration in the context of building an employer brand.

Keywords: transparent remuneration, remuneration openness, openness around wages, employer branding, employer brand

\section{Mgr Urszula Zając-Pałdyna}

Absolwentka prawa oraz zarządzania zasobami ludzkimi. Doktorantka w Instytucie Kapitału Ludzkiego Szkoły Głównej Handlowej w Warszawie. Główne obszary jej zainteresowań naukowych i badawczych to wizerunek przedsiębiorstwa jako pracodawcy oraz jawność wynagrodzeń. Praktyk biznesu - HR Manager, autorka bloga www.hrnaobcasach.pl, czynny trener. Na co dzień doradza firmom w obszarze rekrutacji oraz budowania wizerunku przedsiębiorstwa jako pracodawcy. 